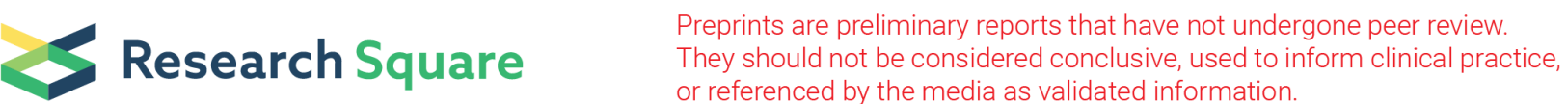

\section{A Common Founder Effect of the Splice Site Variant c.-23+1G>A in GJB2 Gene Causing Autosomal Recessive Deafness 1A (DFNB1A) in Eurasia}

\author{
Aisen V Solovyev \\ M.K. Ammosov North-Eastern Federal Univerity \\ Alena Kushniarevich \\ Estonian Biocentre \\ Elena Bliznetz \\ Research Centre for Medical Genetics \\ Marita Bady-Khoo \\ Federal Research Center Institute of Cytology and Genetics \\ Maria R Lalayants \\ National Research Centre for Audiology and Hearing Rehabilitation

\section{Tatiana G Markova} \\ National Research Centre for Audiology and Hearing Rehabilitation

\section{Gabriel Minárik}

Comenius University in Bratislava Faculty of Medicine: Univerzita Komenskeho v Bratislave Lekarska fakulta

\section{L'udevít Kádasi}

Institute of Molecular Physiology and Genetics Slovak Academy of Sciences: Ustav molekularnej fyziologie a genetiky Slovenskej akademie vied

\section{Ene Metspalu}

Estonian Biocentre

\section{Vera G Pshennikova}

FSBI Yakut Science Centre of Complex Medical Problems: FGBU Akutskij naucnyj centr kompleksnyh medicinskih problem

\section{Fedor M Teryutin}

Yakut Science Centre of Complex Medical Problems

\section{Anatoly N Alekseev}

Institute of Humanities Research and Study of the Indigenous Peoples of the North SB RAS: Institut gumanitarnyh issledovanij i problem malocislennyh narodov Severa SO RAN

\section{Elza K Khusnutdinova}

Institute of Biochemistry and Genetics RAS: Institut biohimii i genetiki RAN

\author{
Alexander Poliakov \\ Research Centre for Medical Genetics \\ Mait Metspalu \\ Estonian Biocentre
}




\section{Olga L Posukh}

Federal Research Center Institute of Cytology and Genetics

\section{Nikolay A Barashkov ( $\square$ barashkov2004@mail.ru )}

FSBI Yakut Science Centre of Complex Medical Problems: FGBU Akutskij naucnyj centr kompleksnyh medicinskih problem https://orcid.org/0000-0002-6984-7934

\section{Sardana A Fedorova}

M.K. Ammosov North-Eastern Federal University

\section{Research Article}

Keywords: c.-23+1G>A, GJB2 gene, autosomal recessive deafness 1A (DFNB1A), founder effect, haplotype analysis

Posted Date: July 7th, 2021

DOI: https://doi.org/10.21203/rs.3.rs-670020/v1

License: (1) This work is licensed under a Creative Commons Attribution 4.0 International License. Read Full License

Version of Record: A version of this preprint was published at Human Genetics on November 27th, 2021. See the published version at https://doi.org/10.1007/s00439-021-02405-w. 


\section{Abstract}

The mutations in the GJB2 gene are known to be a major cause of autosomal recessive deafness 1A (OMIM 220290). The most common pathogenic variants of the GJB2 gene have high ethno-geographic specificity in their distribution that being attributed to a founder effect related with Neolithic migration routes of Homo sapiens. Curiously, the c.-23+1G>A splice site variant is frequently found among deaf patients of both Caucasian and Asian origin. It is currently unknown whether this mutation did spread across Eurasia as a result of the founder effect or it could have multiple local centers of origin. To determine the origin of the c. $-23+1 \mathrm{G}>$ A we reconstructed $f 2$-haplotypes by genotyping SNPs on the Illumina OmniExpress $730 \mathrm{~K}$ platform in 23 deaf individuals homozygous for this variant from different populations of Eurasia (Yakuts, Tuvinians, Evenk, Kumyk, Armenian, Russians and Slovak). The analysis revealed that the homozygosity regions in different individuals overlapped in one short region with the length of $\sim 5.2 \mathrm{~kb}$. These data support the hypothesis of the common founder effect in distribution of the c.-23+1G>A variant of $G J B 2$ gene. Based on the published data on the $\mathrm{c} .23+1 \mathrm{G}>\mathrm{A}$ prevalence among 16,177 deaf people and calculation of TMRCA of the $f 2-$ haplotypes carrying this variant we reconstructed the potential migration routes of the $c .-23+1 \mathrm{G}>\mathrm{A}$ carriers around the world. This analysis indicates that the $\mathrm{c} .23+1 \mathrm{G}>\mathrm{A}$ variant may have originated approximately 6,000 years ago in the territory of the Caucasus or Middle East, followed by spread throughout Europe, South and Central Asia and other regions of the world.

\section{Introduction}

The GJB2 gene (MIM \#121011) encodes the gap junction protein - connexin 26 (Cx26) which is located on the $13 q 12.11$ chromosome region. The connexin 26 protein is found in the cochlea in the inner ear and is a major regulator of $\mathrm{K}^{+}$homeostasis (Dror et al., 2009). In the absence of $\mathrm{K}^{+}$circulation the hair cells are unable to generate action potential in response to sound that leads to autosomal recessive deafness 1A (DFNB1A) (OMIM \#220290). To date, more than 400 different allelic variants have been described in the GJB2 gene (The Human Gene Mutation Database). Many of them have high ethno-geographic specificity in their prevalence (Stenson et al., 2014; Chan and Chang, 2014; Tsukado et al., 2015; del Castillo and del Castillo, 2017), which is attributed to a founder effect for certain ethnic groups (Morell et al., 1998; Van Laer et al., 2001; Shahin et al., 2002; Yan et al., 2003; RamShankar et al., 2003; Rothrock et al., 2003; Balcı et al., 2005; Abidi et al., 2008; Kokotas et al., 2008; Tekin et al., 2010; Barashkov et al., 2011; Dzhemileva et al., 2011; Norouzi et al. 2011; Gallant et al., 2013; Carranza et al., 2016; Bliznetz et al., 2017; Zytsar et al., 2018; Erdenechuluun et al., 2018; Posukh et al., 2019; Shinagawa et al., 2020; Zytsar et al., 2020). The role of common founder effect in prevalence of certain GJB2 mutations was demonstrated: for the c.35delG (p.Gly12fs) variant in Caucasian populations the age was approximately estimated to be the range from 4800-8100 years in Siberia to 14000 years in Mediterranean (Van Laer et al., 2001; Kokotas et al., 2008; Dzhemileva et al., 2011; Zytsar et al., 2018), for the c.235delC (p.Leu79fs) in East Asia ( 11500 years) (Yuan et al., 2010), for the c.72G>A (p.Trp24*) in India ( 7880 years) (Ramshankar et al., 2003), for the c.109G $>A$ (p.Val37lle) in individuals of Asian origin from US ( 7500 years) (Gallant et al., 2013) and for the del(GJB2-D13S175) in North Caucasus (Russia) ( 3000 years) (Bliznetz et al., 2017).

The c.-23+1G $>$ A splice site mutation (originally named IVS1 $+1 \mathrm{G}>A$ ) impairs splicing between non-coding exon 1 and coding exon 2 of the $G J B 2$ gene. The $c .-23+1 G>A$ mutation was first described in Caucasian populations 
(Green et al., 1999; Denoyelle et al., 1999). Today the c.-23+1G>A mutation is found in populations of North and South America, Australia and Europe with average frequency $2.4 \%, 8.6 \%, 3.8 \%$ and $2.3 \%$, respectively, out of all mutant GJB2 chromosomes (Green et al., 1999; D' Andrea et al., 2002; Janecke et al., 2002; Marlin et al., 2005; Santos et al., 2005; Seeman et al., 2006; Pollak et al., 2007; Toth et al., 2007; Utrera et al., 2007; Sansovic et al., 2009; Gravina et al., 2010; Minarik et al., 2012; Radulescu et al., 2012; Dahl et al., 2013; Matos et al., 2013; Hernandez-Juarez et al., 2014; Neocleous et al., 2014; Amorini et al., 2015; Shubina-Oleinik et al., 2015; de Carvalho et al., 2016; Bliznetz et al., 2017). The c.-23+1G>A is the second most frequent mutation of the GJB2 gene in patients with congenital deafness in South Asia (13.2\%) after the c.72G>A (p.Trp24*) mutation, in the Middle East and Caucasus populations (20.0\%) after the c.35delG (p.Gly12fs) mutation (Tekin and Arıcl, 2007; Bajaj et al., 2008; Brownstein et al., 2009; Padma et al., 2009; Al-Qahtani et al., 2010; Al-Achkar et al., 2011; Bozhkova et al., 2011; Bazazzadegan et al., 2012; Bliznetz et al., 2012; Khalifa Alkowari et al., 2012; AlAchkar et al., 2017). Moreover, the c.-23+1G>A is the most common pathogenic GJB2-variant in Central Asia (Mongolia) and Siberia (48.7\%) (Tekin et al., 2010; Barashkov et al., 2016; Erdenechuluun et al., 2018). Extensive accumulation of the $c .-23+1 \mathrm{G}>A$ was found in the indigenous Yakut population of Eastern Siberia (the Sakha Republic, Russia) (82.7\% among all mutant GJB2 chromosomes found in Yakut deaf patients) (Barashkov et al., 2011). The haplotype analysis in the Yakut population showed that the chromosomes with the $\mathrm{c} .23+1 \mathrm{G}>\mathrm{A}$ mutation have a common origin, and the expansion of this mutation in Eastern Siberia was dated to be around 800 years ago (Barashkov et al., 2011).

The haplotype analysis of the chromosomes with c.-23+1G>A mutation in Mongolian population revealed different mutant haplotypes suggesting multiple origin of this mutation in Mongolia (Tekin et al., 2010). However, only one mutant haplotype was found in Turkish patients, which was similar to a major haplotype found in Mongolia (Tekin et al., 2010). In the recent study, five different haplotypes in deaf patients from six Eurasian populations homozygous for mutation c. $-23+1 \mathrm{G}>\mathrm{A}$ (Yakuts, Russians, Evenks, Tuvinians, Mongols and Turks) were reconstructed based on the analysis of variability of nine SNP markers (Tekin et al., 2010; Solovyev et al., 2017). The structure of the mutant haplotypes was similar in all studied populations and one haplotype (GTACCAGAC) was prevalent: Mongolians (62.5\%), Yakuts (99.1\%), Russians (100\%), Evenks $(100 \%)$, Tuvinians $(100 \%)$ and Turks $(100 \%)$. These data suggest the distribution of this mutation across Eurasia was a result of the founder effect (Solovyev et al., 2017). However, the studied SNP markers do not have high variability in studied populations, so the issue of defining migration routes of the $c .-23+1 \mathrm{G}>\mathrm{A}$ mutation carriers requires a further in-depth study with an increased resolution. Thereby, it is currently unknown whether this mutation did spread across Eurasia as a result of the founder effect or could it have had several local centers of origin?

The aim of this work to determine haplotypes with the $c .-23+1 \mathrm{G}>A$ mutation of $G J B 2$ gene based on the genome-wide analysis of deaf patients from different regions of Eurasia to determine the origin and reconstruct the possible migration routes of the $\mathrm{c} .-23+1 \mathrm{G}>\mathrm{A}$ mutation.

\section{Materials And Methods}

\section{Samples and genotyping}


To increase the reliability of the mutant haplotypes detection and avoid Phasing probabilities for this study, we focused only on the individuals with hearing loss diagnosis and who were homozygous for the c.-23+1G>A mutation in the GJB2 gene. To answer the question about the common origin of the mutation, we collected 23 DNA samples of deaf individuals from different regions of Eurasia (14 Yakuts, 3 Tuvinians, 2 Russians, 1 Evenk, 1 Kumyk, 1 Armenian, and 1 Slovak). Anthropological, linguistic, and geographical affiliations of deaf individuals are presented in Table 1. DNA was extracted from blood leukocytes using the phenol-chloroform method. All participants gave written informed consent for participation in the study.

All 23 individuals were genotyped using the Illumina OmniExpress $730 \mathrm{~K}$ array according to the manufacturer's specifications. The missing data value was less than $5 \%$. The absence of cryptic relatedness corresponding to the first and second-degree relatives in our dataset was confirmed using the KING software (Manichaikul et al., 2010). A clean data set of 693,521 autosomal variants only was obtained, with chromosome 13 having 26,626 variants.

\section{PC and ADMIXTURE analysis}

To conduct PC and ADMIXTURE analysis, we combined newly generated genotypes with the data from previous studies (Li et al., 2008; Rasmussen et al., 2010; Behar et al., 2010; Yunusbayev et al., 2012; Metspalu et al., 2011; Fedorova et al., 2013; Raghavan et al, 2014; Behar et al., 2013). Individuals with more than 1.5\% missing genotypes were excluded from the combined dataset. Only markers with a $97 \%$ genotyping rate and minor allele frequency (MAF) > 1\% were retained. The marker set was thinned by excluding SNPs in strong LD (pairwise genotypic correlation $r 2>0.4$ ) in a window of 1000 SNPs, sliding the window by 150 SNPs at a time. The final dataset included 242,229 SNPs presented in 391 individuals from 24 different world populations and in 23 individuals homozygous for the c.-23+1G>A. The PCA was performed for the autosomal dataset using the "smartpca" software of the EIGENSOFT package (Patterson et al., 2006). We inferred population structure in our dataset using a model-based clustering method implemented in the ADMIXTURE software (Alexander et al., 2009). We performed ADMIXTURE assuming $\mathrm{K}=2$ to $\mathrm{K}=10$ genetic clusters in 100 replicates and assessed convergence between individual runs. We found that the best clustering solution that met our selection criteria was $\mathrm{K}=8$.

\section{Analysis of the region flanking the $c .-23+1 \mathrm{G}>\mathrm{A}$ mutation}

The search for a likely common region in the sample was carried out by comparing the allele frequencies according to the beta distribution function. The beta distribution can accurately describe the stochastic behavior in time of allele frequencies and the influence of evolutionary pressures, such as mutation and selection (Tataru et al., 2015). By this method, we compared the frequency of the allele "A" with the frequency of the allele "B". If the frequency of these alleles is significantly different, the most frequent allele is selected. Then algorithm checks the next position values of the beta distribution, alleles are included in one common chromosomal region if the values overlap. This continues until there are alleles without statistically significant values. To evaluate the reliability of identified common chromosomal regions, we used the following equation:

$\mathrm{R}=\ln (\mathrm{L} \times \mathrm{SNP})$ 
where, $\mathrm{R}$ - rating of reliability of the common chromosomal region; $\mathrm{L}$ - length of the tested common chromosomal region in bp; SNP - number of SNPs in the tested common chromosomal region.

This reduces credibility of long homozygous region with a small number of SNPs and increases credibility of the homozygous region with high number of SNPs. In the end we get a file where indicated: the start position, the $\mathrm{P}$ value, and the end position of the common chromosomal regions in chromosome. This analysis is similar to a combination of RoH and GWAS analyses, but it is more sensitive and does not require a large number of samples. This method does not use a moving window that potentially introduces artificial runs and fails to capture runs larger than the window, instead it analyses all alleles and chromosomes in parallel, which also increases the calculation speed.

For a detailed analysis of homozygosity regions, we scanned chromosome 13 in each individual starting from the c.-23+1G>A mutation position in the left and right directions until the first heterozygous allele position. We did not consider the physical distances between SNPs.

\section{The $f$ 2-haplotypes method and age dendrogram}

The $f$ 2-haplotype was found by pairwise comparison of individuals with each other. From the point of the c. $-23+1 \mathrm{G}>\mathrm{A}$ mutation, where we scan left and right along the chromosome until we reach a point where two individuals have inconsistent homozygote genotypes, which gives us an (over-) estimate of the distance to the first recombination breaking the haplotype (Mathieson and McVean, 2014). This approach is highly scalable and finds shared haplotypes directly from genotype data, which avoids the need for statistical phasing. Then we use the length of, and the number of non-matching markers on this haplotype to infer their ages, and therefore a lower bound for the age of the variants they carry.

The $f$ 2-haplotype age was calculated by the TMRCA (the Time to Most Recent Common Ancestor) software by the University of Illinois at Urbana-Champaign available in the public domain (http://faculty.scs.illinois.edu/ mcdonald/tmrca.htm). We considered the mutation rate as $1 \cdot 10^{-8}$ of per-base per-generation. The mutation rate was given to each model for converting TMRCA from coalescence unit to years, taking into account the average mutation rate probability based on physical lengths of $f 2$-haplotypes and numbers of SNP-markers. It should be noted that an accurate age calculation of the GJB2 region was obstructed because of many uncertainties. The age dendrogram was created with the UPGMA method based on the ages of each $f$ 2-haplotype.

\section{Table 1. Anthropological, linguistic and geographical affiliation of 23 deaf patients homozygous for the c. $-23+1 \mathrm{G}>A$ splice site mutation in GJB2 gene}




\begin{tabular}{|c|c|c|c|c|c|}
\hline Population & $\begin{array}{l}\text { Number } \\
\text { of deaf } \\
\text { patients } \\
(n= \\
23)\end{array}$ & $\begin{array}{l}\text { Anthropological } \\
\text { affiliation }\end{array}$ & Linguistic affiliation & $\begin{array}{l}\text { Location } \\
\text { (Province/Country) }\end{array}$ & $\begin{array}{l}\text { Geographical } \\
\text { region }\end{array}$ \\
\hline Evenks & 1 & Asian & $\begin{array}{l}\text { Altaic/ } \\
\text { Tungusic }\end{array}$ & $\begin{array}{l}\text { Republic of Sakha } \\
\text { (Yakutia) / Russia }\end{array}$ & $\begin{array}{l}\text { Eastern } \\
\text { Siberia }\end{array}$ \\
\hline Yakuts & 14 & Asian & $\begin{array}{l}\text { Altaic/ } \\
\text { Turkic }\end{array}$ & $\begin{array}{l}\text { Republic of Sakha } \\
\text { (Yakutia) / Russia }\end{array}$ & $\begin{array}{l}\text { Eastern } \\
\text { Siberia }\end{array}$ \\
\hline Tuvinians & 3 & Asian & $\begin{array}{l}\text { Altaic/ } \\
\text { Turkic }\end{array}$ & $\begin{array}{l}\text { Republic of } \\
\text { Tyva / Russia }\end{array}$ & $\begin{array}{l}\text { Southern } \\
\text { Siberia }\end{array}$ \\
\hline Kumyks & 1 & Caucasian & $\begin{array}{l}\text { Altaic/ } \\
\text { Turkic }\end{array}$ & $\begin{array}{l}\text { Republic of } \\
\text { Dagestan / Russia }\end{array}$ & $\begin{array}{l}\text { North } \\
\text { Caucasus }\end{array}$ \\
\hline Armenians & 1 & Caucasian & $\begin{array}{l}\text { Indo- } \\
\text { European / Armenian }\end{array}$ & Erevan / Armenia & $\begin{array}{l}\text { South } \\
\text { Caucasus }\end{array}$ \\
\hline \multirow[t]{2}{*}{ Russians } & 2 & Caucasian & $\begin{array}{l}\text { Indo- } \\
\text { European / Slavic }\end{array}$ & $\begin{array}{l}\text { Vladimir oblast' / } \\
\text { Russia }\end{array}$ & $\begin{array}{l}\text { Eastern } \\
\text { Europe }\end{array}$ \\
\hline & & & & $\begin{array}{l}\text { Voronezh oblast' / } \\
\text { Russia }\end{array}$ & $\begin{array}{l}\text { Eastern } \\
\text { Europe }\end{array}$ \\
\hline Slovaks & 1 & Caucasian & $\begin{array}{l}\text { Indo- } \\
\text { European / Slavic }\end{array}$ & Trenčín / Slovakia & $\begin{array}{l}\text { Central } \\
\text { Europe }\end{array}$ \\
\hline
\end{tabular}

\section{Results}

\section{Ancestral background}

To answer the question about the common origin of the c.-23+1G>A mutation, we collected 23 DNA samples of deaf people from different regions of Eurasia (14 Yakuts, 3 Tuvans, 2 Russians, 1 Evenk, 1 Kumyk, 1 Armenian and 1 Slovak) (Fig. 1A). To confirm the ethnic identity of patients, we compared their genetic components with different populations of the world using PC analysis (Patterson et al., 2006) and performed a global ancestry inference with ADMIXTURE (Alexander et al., 2009). For the PC and ADMIXTURE analysis, we combined our patients genotypes with the data from previous studies (Li et al., 2008; Rasmussen et al., 2010; Behar et al., 2010; Yunusbayev et al., 2012; Metspalu et al., 2011; Fedorova et al., 2013; Raghavan et al, 2014; Behar et al. 2013). Figure 1 shows that all individuals homozygous for c.-23+1G>A clustered according to their ethnic identity and geographic origin (Fig. 1B). The ADMIXTURE analysis $(K=8)$ confirms that the ancestral composition of each studied individual corresponds to the ones of a respective population (Fig. 1C). Thus, the results of both analyses (PC and ADMIXTURE) demonstrate that genetic profiles of all samples with c. $-23+1 \mathrm{G}>\mathrm{A}$ substitution correspond to their geographic location and ethnic origin. 
In this study, we used a new method that considers the likelihood of allele frequencies by the function of the beta distribution. This analysis detects the most probable extended regions of linked alleles in the studied samples and resemble the GWAS analysis but considers the length of the common chromosomal region making it possible to work on a small sample. On the figure $2 A$ it is shown that the study sample has a long common region flanking the $c .-23+1 \mathrm{G}>\mathrm{A}$ mutation on chromosome $13(R=14.11)$. No such long common chromosomal regions were detected on other autosomes (Fig. 2A).

Detailed analysis of the homozygosity regions flanking the c. $-23+1 \mathrm{G}>\mathrm{A}$ mutation showed that their length varied between individuals with different ancestral backgrounds (Fig. 2B). Shorter homozygous regions were found in individuals from Eastern and Central Europe (Russian - 18.9 kb, Slovak - 296.3 kb) and from Caucasus populations (Armenian - 29.2 kb, Kumyk - 96.6 kb), while these regions were longer in Siberian individuals (Tuvinians, Southern Siberia) having the longest homozygosity regions (from 2.7 to 7.6 Mb). Despite the differences in the length of the homozygosity regions for each individual, all of them overlap in the 5.2 kb chromosomal region (5 SNPs: rs7329857, rs3751385, rs2274083, rs2274084 and rs7987144). But this haplotype (GCTCC) is typical for most of the populations presented in the NCBI database (The 1000 Genomes Project Consortium).

\section{Mutation age}

In our case, we cannot use the LD structure to calculate the age of the mutation, because the LD structure will be calculated based on the majority of people in our sample (Yakuts). To avoid this, we used a more simplified method of $f$ 2-haplotype (Mathieson and McVean, 2014) for the calculation of the time to the most recent common ancestor (TMRCA). This method is suitable for the hypothetical estimation of the closest common ancestor between two haplotypes. We determined the lengths of the $f 2$-haplotypes by pairwise comparison of each individual from the position of the $\mathrm{c} .23+1 \mathrm{G}>\mathrm{A}$ mutation to the position where both individuals have different homozygous alleles (Fig. 3). The samples from the Caucasus (Kum, Arm) and Europe (Rus2) have short $f$ 2-haplotypes being equidistant from other studied samples and composing the European cluster. Conversely, the longest haplotypes were found in Siberian cluster (Yak1-2, Yak4-5, Yak8, Yak13, Evk) which also included one Russian sample (Rus1). The intermediate cluster begins with Slovak (Slv) samples and included the Yakuts (Yak3, Yak9-10) and Tuvinians (Tuv1-3) samples, where the Tuvinian samples form a small group.

Using both the genetic and physical lengths of the region, and the number of the conditional number of heterozygous alleles that our genotyping resolution allows, we have calculated approximate haplotype age. The TMRCA results based on the $f$ 2-haplotype method give an approximate age of the divergence of the mutant haplotypes but not of individuals in general. The obtained results indicated the more distant mutant $f$ 2-haplotypes in the samples of Caucasus (Kum, Arm) and Europe (Rus2) (Fig. 4). Common ancestor for all samples lived $~ 245$ generations ago (if duration of one generation is considered as 25 years, then the approximate age of the mutation $\sim 6125$ years).

\section{Discussion}


For the genome-wide reconstruction of haplotypes with the c.-23+1G>A mutation in the GJB2 gene, we collected DNA samples from 23 deaf individuals with confirmed c. $-23+1 \mathrm{G}>\mathrm{A}$ mutation in the homozygous state. The samples have different anthropological and linguistic affiliations (Yakuts, Tuvinians, Evenk, Kumyk, Armenian, Russians and Slovak) from four regions of Eurasia - Siberia, Caucasus, Eastern and Central Europe (Fig. 1A). Thus, to confirm the geographic location and ethnic origin reported by the sample donors, as the first stage of our study, we performed the PC and ADMIXTURE analyses in the context of worldwide populations. In the PC analysis, all samples with c. $-23+1 \mathrm{G}>\mathrm{A}$ mutation clustered according to their ethnic identity and geographic origin (Fig. 1B). The ADMIXTURE analysis ( $\mathrm{K}=8$ ) confirmed the ancestral composition of each studied individual corresponds to a respective population (Fig. 1C). The results of both analyses (PC and ADMIXTURE) demonstrated that genetic profiles of all samples with c. $-23+1 \mathrm{G}>\mathrm{A}$ mutation correspond to their geographic location and ethnic origin and exclude the likelihood of distant relationship between observed patients (Fig. 1B, C).

On the next step, the analysis of the homozygosity on chromosome 13 for each sample revealed a common homozygous segment of $\sim 5.2 \mathrm{~kb}$ (from 20762929 to 20768144 position), flanking the c. $-23+1 \mathrm{G}>\mathrm{A}$ mutation (Fig. 2B). However, this common homozygous segment containing 5 SNPs (rs7329857, rs3751385, rs2274083, rs2274084 and rs7987144) is typical for most worldwide populations (GCTCC) (The 1000 Genomes Project Consortium). Recombination in the chromosome is random and the distribution of runs of homozygosity $(\mathrm{ROH})$ on samples is likely to be uneven and there is a high probability that the common chromosomal region with the mutation in the homozygous state will be shorter than it actually is. In this study, to confirm the common chromosomal region associated with the $\mathrm{c} .-23+1 \mathrm{G}>\mathrm{A}$ mutation in a small number of samples, we applied a new approach, which takes into account the state of the SNP position relative to the probability of divergence of alleles by the beta distribution function and its length. The new analysis showed that all studied samples have long homozygous regions flanking the $c .-23+1 G>A$ on chromosome $13(R=14.11)$. No such long homozygosity regions were detected on other autosomes (Fig. 2A). These facts indirectly indicate the more ancient time of the spread of $\mathrm{c} .-23+1 \mathrm{G}>\mathrm{A}$ mutation and support the hypothesis of the common founder effect of the c. $-23+1 \mathrm{G}>\mathrm{A}$ mutation in the GJB2 gene.

To elucidate the origin of this mutation and reconstruct possible migration routes of $c .-23+1 \mathrm{G}>\mathrm{A}$ carriers, we analyzed the published data about the prevalence of c.-23+1G>A among 16,177 deaf people around the world (Supplementary Table). This analysis showed that c. $-23+1 \mathrm{G}>\mathrm{A}$ mutation is present with various frequencies on almost all continents of the world (from $0.6 \%$ in East Asia to $58.1 \%$ in Siberia and Central Asia), except for South-East Asia and Sub-Saharan Africa (Supplementary Table). Based on the data about the extensive accumulation of the $\mathrm{c}-23+1 \mathrm{G}>\mathrm{A}$ mutation, there are three possible geographic regions from which this mutation could begin to spread: Central Asia, the Caucasus or Middle East and South Asia (Fig. 5). However, it is unlikely that the center of origin may be in South Asia because this mutation was found almost in all regions of the world (Fig. 5). In addition, earlier we considered that the c.-23+1G>A mutation could begin to spread from Central Asia across Eurasia and only after then spread out around the world (Solovyev et al., 2017). This hypothesis was based on the highest observed frequency of this mutation in the territory of Central Asia and Siberia and the highest diversity of haplotypes with the $c .-23+1 \mathrm{G}>\mathrm{A}$ in patients from Mongolia. However, the results of the current study do not support this hypothesis, since we have found shorter homozygosity regions in individuals from Europe (Russian - 18.9 kb, Slovak - $296.3 \mathrm{~kb}$ ) and the Caucasus (Armenians - 29.2 kb, Kumyks - 96.6 kb) (Fig. 2B). A relatively short homozygosity region can 
indicate on the more ancient haplotypes with this mutation in populations of the Caucasus and Europe, and on the contrary, the relatively recent distribution of this pathogenic variant among Central Asian and Siberian populations.

To test this hypothesis, we analyzed the $f$ 2-haplotypes using both the genetic and physical lengths of the haplotype and the number of the heterozygous alleles, which allow us to observe changes in the structure of the haplotype over time and display the demographic events. The analysis of the $f 2$-haplotypes length data showed that individuals from populations of the Caucasus and Europe (Kum, Arm and Rus2) carried more divergent haplotypes than other studied individuals (Fig. 3). The TMRCA calculation of the $f 2$-haplotypes showed that the most recent common ancestor with c.-23+1G>A lived not less than 6,000 years ago (Fig. 4). Thereby, the data on the more ancient c.-23+1G>A haplotypes from populations of the Caucasian origin (Kum, Arm and Rus2) points to the fact that $\mathrm{c} .-23+1 \mathrm{G}>\mathrm{A}$ mutation originated somewhere in the regions of the Caucasus or Middle East and then spread throughout Europe, Central Asia and South Asia. The possible geographical center of origin of the c.-23+1G>A, its frequency among all mutant GJB2 chromosomes in different world populations and assumed migration routes of the $\mathrm{c} .-23+1 \mathrm{G}>\mathrm{A}$ carriers are presented in Figure 5.

It is interesting that the prevalence of $c .-23+1 \mathrm{G}>\mathrm{A}$ in the world is quite comparable to the hypothetical routes of expansion of Indo-European languages ( 4000 - 2500 BC) across Europe, Middle East, the Caucasus and South Asia (Tassi et al., 2017). Moreover, the world prevalence of the c.23+1G>A corresponds to the expansion of populations of European descent, which are widely presented in North America and Australia, and also had a significant impact on the genetic structure in modern populations of South America and Siberia. The extremely high frequency of c.-23+1G>A among indigenous populations in Central Asia and Siberia may represent a random population effect and can be explained by the genetic structure and demographic events in the history of these populations.

\section{Conclusion}

The obtained results support the hypothesis of common origin of mutation c.-23+1G>A in $G J B 2$ gene. It is most likely that c. $-23+1 \mathrm{G}>\mathrm{A}$ originated in the territory of the Caucasus or Middle East and only then spread throughout in Europe, South Asia, Central Asia and Siberia.

\section{Declarations}

\section{Acknowledgments}

We thank all patients and blood sample donors who have contributed to this study. This study was supported by the Yakut Science Centre of Complex Medical Problems project: "Study of the genetic structure and burden of hereditary pathology of populations of the Republic of Sakha (Yakutia)", the Ministry of Science and Higher Education of the Russian Federation (FSRG-2020-0016), the Russian Foundation for Basic Research (\#18-05600035_Arctika, \# 20-015-00328_A), the European Union through the European Regional Development Fund (Project No. 2014-2020.4.01.15-0012) and IUT 24 Research Funding of the Institutional Estonian Ministry of Education and Research.

\section{Conflict of interest}


On behalf of all authors, the corresponding author states that there is no conflict of interest.

\section{Ethical approval}

This study was approved by the local Biomedical Ethics Committee at the Yakut Scientific Center of Complex Medical Problems, Yakutsk, Russia (Yakutsk, Protocol No. 50, 24 December 2019).

\section{Consent to participate}

Informed consent for genetic analyses was obtained from all individual participants included in this study.

\section{Consent for publication}

All the authors agreed that this manuscript be submitted to the journal of Human Genetics for publication.

\section{Code availability}

Bioinformatic analyses were done with publicly available software packages as described in the methods. Custom codes to aid in variant filtering are available upon request.

\section{References}

Abidi O, Boulouiz R, Nahili H, Imken L, Rouba H, Chafik A, Barakat A (2008) The analysis of three markers flanking GJB2 gene suggests a single origin of the most common 35delG mutation in the Moroccan population. Biochemical and Biophysical Research Communications 377(3):971-4. https://doi.org/10.1016/j.bbrc.2008.10.086

Al-Achkar W, Moassass F, Al-Halabi B, Al-Ablog A (2011) Mutations of the Connexin 26 gene in families with non-syndromic hearing loss. Molecular Medicine Reports 4(2): :331-5. https://doi.org/10.3892/mmr.2011.428

AL-Achkar W, AL-Halabi B, Ali B, Moassass F (2017) First report of prevalence c.IVS1+1G>A and del(GJB613S1854) mutations in Syrian families with non-syndromic sensorineural hearing loss. International Journal of Pediatric Otorhinolaryngology 92:82-87. https://doi.org/10.1016/j.ijporl.2016.11.15

Al-Qahtani MH, Baghlab I, Chaudhary AG, Abuzenadah AM, Bamanie A, Daghistani KJ, Safieh M, Fida L, Dallol A (2010) Spectrum of GJB2 Mutations in a Cohort of Nonsyndromic Hearing Loss Cases from the Kingdom of Saudi Arabia. Genetic Testing and Molecular Biomarkers 14(1):79-83.

https://doi.org/10.1089/gtmb.2009.111

Alexander DH, Novembre J, Lange K (2009) Fast model-based estimation of ancestry in unrelated individuals. Genome Research 19(9):1655-64. https://doi.org/10.1101/gr.094052.109

Amorini M, Romeo P, Bruno R, Galletti F, Di Bella C, Longo P, Briuglia S, Salpietro C, Rigoli L (2015) Prevalence of Deafness-Associated Connexin-26 (GJB2) and Connexin-30 (GJB6) Pathogenic Alleles in a Large Patient Cohort from Eastern Sicily. Annals of Human Genetics 79(5):341-349. https://doi.org/10.1111/ahg.12120 
Bajaj Y, Sirimanna T, Albert D, Qadir P, Jenkins L, Bitner-Glindzicz M (2008) Spectrum of GJB2 mutations causing deafness in the British Bangladeshi population. Clinical Otolaryngology 33(4):313-318.

https://doi.org/10.1111/j.1749-4486.2008.1754.x

Balci B, Gerçeker FO, Aksoy S, Sennaroğlu G, Kalay E, Sennaroğlu L, Dinçer P (2005) Identification of an ancestral haplotype of the $35 \mathrm{delG}$ mutation in the GJB2 (connexin 26) gene responsible for autosomal recessive non-syndromic hearing loss in families from the Eastern Black Sea Region in Turkey. The Turkish Journal of Pediatrics 47(3):213-21.

Barashkov NA, Dzhemileva LU, Fedorova SA, Teryutin FM, Posukh OL, Fedotova EE, Lobov SL, Khusnutdinova EK (2011) Autosomal recessive deafness 1A (DFNB1A) in Yakut population isolate in Eastern Siberia:

extensive accumulation of the splice site mutation IVS1+1G>A in GJB2 gene as a result of founder effect. Journal of Human Genetics 56(9):631-9. https://doi.org/10.1038/jhg.2011.72

Bazazzadegan N, Nikzat N, Fattahi Z, Nishimura C, Meyer N, Sahraian S, Jamali P, Babanejad M, Kashef A, Yazdan H, Sabbagh Kermani F, Taghdiri M, Azadeh B, Mojahedi F, Khoshaeen A, Habibi H, Reyhanifar F, Nouri N, Smith RJ, Kahrizi K, Najmabadi H (2012) The spectrum of GJB2 mutations in the Iranian population with non-syndromic hearing loss-A twelve year study. International Journal of Pediatric Otorhinolaryngology 76(8):1164-1174. https://doi.org/10.1016/j.ijporl.2012.4.26

Behar DM, Metspalu M, Baran Y, Kopelman NM, Yunusbayev B, Gladstein A, Tzur S, Sahakyan H, Bahmanimehr A, Yepiskoposyan L, Tambets K, Khusnutdinova E, Kushniarevich A, Balanovsky O, Balanovsky E, Kovacevic L, Marjanovic D, Mihailov E, Kouvatsi A, Triantaphyllidis C, King RJ, Semino O, Antonio Torroni A, Hammer MF, Metspalu E, Skorecki K, Rosset S, Halperin E, Villems R, Rosenberg NA (2013) No evidence from genome-wide data of a Khazar origin for the Ashkenazi Jews. Human Biology 85(6):859-900. https://doi.org/10.3378/027.085.0604

Behar DM, Yunusbayev B, Metspalu M, Metspalu E, Rosset S, Parik J, Rootsi S, Chaubey G, Kutuev I, Yudkovsky G, Khusnutdinova EK, Balanovsky O, Semino O, Pereira L, Comas D, Gurwitz D, Bonne-Tamir B, Parfitt T, Hammer MF, Skorecki K, Villems R (2010) The genome-wide structure of the Jewish people. Nature 466(7303):238-42. https://doi.org/10.1038/nature09103

Bliznets EA, Marcul' DN, Khorov OG, Markova TG, Poliakov AV (2014) The mutation spectrum of the GJB2 gene in Belarussian patients with hearing loss. Results of pilot genetic screening of hearing impairment in newborns. Genetika 50(2):214-21.

Bliznetz EA, Lalayants MR, Markova TG, Balanovsky OP, Balanovska EV, Skhalyakho RA, Pocheshkhova EA, Nikitina NV, Voronin SV, Kudryashova EK, Glotov OS, Polyakov AV (2017) Update of the GJB2/DFNB1 mutation spectrum in Russia: a founder Ingush mutation del(GJB2-D13S175) is the most frequent among other large deletions. Journal of Human Genetics 62(8):789-795. https://doi.org/10.1038/jhg.2017.42

Bozhkova VP, Khashayev ZKH, Magomedov SHM (2011) Izucheniye nasledstvennykh narusheniy slukha u detey Severnogo Kavkaza. Fundamental'nyye issledovaniya 5:23-27. (in Russian) 
Brownstein Z, Avraham KB (2009) Deafness Genes in Israel: Implications for Diagnostics in the Clinic. Pediatric Research 66(2):128-134. https://doi.org/10.1203/pdr.0b013e3181aabd7f

Carranza C, Menendez I, Herrera M, Castellanos P, Amado C, Maldonado F, Rosales L, Escobar N, Guerra M1, Alvarez D, Foster J 2nd, Guo S, Blanton SH, Bademci G, Tekin M (2015) A Mayan founder mutation is a common cause of deafness in Guatemala. Clinical Genetics 89(4):461-465.

https://doi.org/10.1111/cge.12676

Chan DK, Chang KW (2014) GJB2-associated hearing loss: systematic review of worldwide prevalence, genotype, and auditory phenotype. Laryngoscope 124(2):E34-53. https://doi.org/10.1002/lary.24332

D’Andrea P, Veronesi V, Bicego M, Melchionda S, Zelante L, Di lorio E, Bruzzone R, Gasparini P (2002) Hearing loss: frequency and functional studies of the most common connexin26 alleles. Biochemical and Biophysical Research Communications 296(3):685-691. https://doi.org/10.1016/s0006-291x(02)00891-4

Dahl HHM, Ching TYC, Hutchison W, Hou S, Seeto M, Sjahalam-King J (2013) Etiology and Audiological Outcomes at 3 Years for 364 Children in Australia. PLoS ONE 8(3):e59624.

https://doi.org/10.1371/journal.pone.59624

de Carvalho GMZ, Ramos PM, Castilho AC, Guimarães AL, Sartorato E (2016) Relationship Between Patients with Clinical Auditory Neuropathy Spectrum Disorder and Mutations in GJB2 Gene. The Open Neurology Journal 10(1):127-135. https://doi.org/10.2174/1874205x01610010127

del Castillo FJ and del Castillo I (2017) DFNB1 Non-syndromic Hearing Impairment: Diversity of Mutations and Associated Phenotypes. Front. Mol. Neurosci. 10:428. doi: 10.3389/fnmol.2017.00428

Denoyelle F, Marlyn S, Weil D, Moatti D, Chauvin P, Garabédian EN, Petit C (1999) Clinical features of the prevalent form of childhood deafness, DFNB1, due to a Connexin-26 gene defect: implications for genetic counseling. Lancet 353(9161):1298-1303. https://doi.org/10.1016/S0140-6736(98)11071-1

Dror AA, Avraham KB (2009) Hearing loss: mechanisms revealed by genetics and cell biology. Annual Review of Genetics 43:411-437. https://doi.org/10.1146/annurev-genet-102108-134135

Dzhemileva LU, Posukh OL, Barashkov NA, Fedorova SA, Teryutin FM, Akhmetova VL, Khidiyatova IM, Khusainova RI, Lobov SL, Khusnutdinova EK (2011) Haplotype Diversity and Reconstruction of Ancestral Haplotype Associated with the c.35delG Mutation in the GJB2 (Cx26) Gene among the Volgo-Ural Populations of Russia. Acta Naturae 3(3):52-63.

Erdenechuluun J, Lin YH, Ganbat K, Bataakhuu D, Makhbal Z, Tsai CY, Lin YH, Chan YH, Hsu CJ, Hsu WC, Chen PL, Wu CC (2018) Unique spectra of deafness-associated mutations in Mongolians provide insights into the genetic relationships among Eurasian populations. PLoS One 13(12):e0209797.

https://doi.org/10.1371/journal.pone.0209797

Fedorova SA, Reidla M, Metspalu E, Metspalu M, Rootsi S, Tambets K, Trofimova N, Zhadanov SI, Kashani BH, Olivieri A, Voevoda MI, Osipova LP, Platonov FA, Tomsky MI, Khusnutdinova EK, Torroni A, Villems R (2013) 
Autosomal and uniparental portraits of the native populations of Sakha (Yakutia): implications for the peopling of Northeast Eurasia. BMC Evolutionary Biology 13:127. https://doi.org/10.1186/1471-2148-13-127

Gallant E, Francey L, Tsai EA, Berman M, Zhao Y, Fetting H, Kaur M, Deardorff MA, Wilkens A, Clark D, Hakonarson H, Rehm HL, Krantz ID (2013) Homozygosity for the V37I GJB2 mutation in fifteen probands with mild to moderate sensorineural hearing impairment: further confirmation of pathogenicity and haplotype analysis in Asian populations. American Journal of Medical Genetics A 161A(9):2148-57.

https://doi.org/10.1002/ajmg.a.36042

Gravina LP, Foncuberta ME, Prieto ME, Garrido J, Barreiro C, Chertkoff L (2010) Prevalence of DFNB1 mutations in Argentinean children with non-syndromic deafness. Report of a novel mutation in GJB2. International Journal of Pediatric Otorhinolaryngology 74(3):250-254.

https://doi.org/10.1016/j.ijporl.2009.11.14

Green GE (1999) Carrier Rates in the Midwestern United States for GJB2 Mutations Causing Inherited Deafness. JAMA 281(23):2211. https://doi.org/10.1001/jama.281.23.2211

Hernández-Juárez AA, Lugo-Trampe JDJ, Campos-Acevedo LD, Lugo-Trampe A, Treviño-González JL, de-laCruz-Ávila I, Martínez-de-Villarreal LE (2014) GJB2 and GJB6 mutations are an infrequent cause of autosomalrecessive nonsyndromic hearing loss in residents of Mexico. International Journal of Pediatric Otorhinolaryngology 78(12):2107-2112. https://doi.org/10.1016/j.ijporl.2014.9.16

Janecke AR, Hirst-Stadlmann A, Günther B, Utermann B, Müller T, Löffler J, Utermann G, Nekahm-Heis D (2002) Progressive hearing loss, and recurrent sudden sensorineural hearing loss associated with GJB2 mutations phenotypic spectrum and frequencies of GJB2 mutations in Austria. Human Genetics 111(2):145-153. https://doi.org/10.1007/s00439-002-0762-y

Khalifa Alkowari M, Girotto G, Abdulhadi K, Dipresa S, Siam R, Najjar N, Badii R, Gasparini P (2011) GJB2 and GJB6 genes and the $A 1555 \mathrm{G}$ mitochondrial mutation are only minor causes of nonsyndromic hearing loss in the Qatari population. International Journal of Audiology 51(3):181-185.

https://doi.org/10.3109/14992027.2011.625983

Kokotas H, Van Laer L, Grigoriadou M, lliadou V, Economides J, Pomoni S, Pampanos A, Eleftheriades N, Ferekidou E, Korres S, Giannoulia-Karantana A, Van Camp G, Petersen MB (2008) Strong linkage disequilibrium for the frequent GJB2 35delG mutation in the Greek population. American Journal of Medical Genetics A 146A(22):2879-84. https://doi.org/10.1002/ajmg.a.32546

Li JZ, Absher DM, Tang H, Southwick AM, Casto AM, Ramachandran S, Cann HM, Barsh GS, Feldman M, Cavalli-Sforza LL, Myers RM (2008) Worldwide human relationships inferred from genome-wide patterns of variation. Science 319(5866):1100-4. https://doi.org/10.1126/science.1153717

Manichaikul A, Mychaleckyj JC, Rich SS, Daly K, Sale M, Chen WM (2010) Robust relationship inference in genome-wide association studies. Bioinformatics 26(22):2867-73.

https://doi.org/10.1093/bioinformatics/btq559

Page 14/23 
Marlin S, Feldmann D, Blons H, Loundon N, Rouillon I, Albert S, Chauvin P, Garabédian EN, Couderc R, Odent S, Joannard A, Schmerber S, Delobel B, Leman J, Journel H, Catros H, Lemarechal C, Dollfus H, Eliot MM, Delaunoy J-L, David A, Calais C, Drouin-Garraud V, Obstoy M-F, Goizet C, Duriez F, Fellmann F, Hélias J, Vigneron J, Montaut B, Matin-Coignard D, Faivre L, Baumann C, Lewin P, Petit C, Denoyelle F (2005) GJB2 and GJB6 Mutations. Archives of Otolaryngology-Head \& Neck Surgery 131(6):481.

https://doi.org/10.1001/archotol.131.6.481

Mathieson I, McVean G (2014) Demography and the Age of Rare Variants. PLoS Genet 10(8):e1004528. https://doi.org/10.1371/journal.pgen.1004528

Matos TD, Simões-Teixeira H, Caria H, Gonçalves AC, Chora J, Correia MDC, Moura C, Rosa H, Monteiro L, O'Neill A, Dias S, Andrea M, Fialho G (2013) Spectrum and frequency of GJB2 mutations in a cohort of 264 Portuguese nonsyndromic sensorineural hearing loss patients. International Journal of Audiology 52(7):466471. https://doi.org/10.3109/14992027.2013.783719

Metspalu M, Romero IG, Yunusbayev B, Chaubey G, Mallick CB, Hudjashov G, Nelis M, Mägi R, Metspalu E, Remm M, Pitchappan R, Singh L, Thangaraj K, Villems R, Kivisild T (2011) Shared and Unique Components of Human Population Structure and Genome-Wide Signals of Positive Selection in South Asia. American Journal of Medical Genetics 89(6):731-44. https://doi.org/10.1016/j.ajhg.2011.11.010

Minarik G, Tretinarova D, Szemes D (2012) Prevalence of DFNB1 mutations in Slovak patients with nonsyndromic hearing loss. International Journal of Pediatric Otorhinolaryngology 76(3):400-403.

https://doi.org/10.1016/j.ijporl.2011.12.020

Morell RJ, Kim HJ, Hood LJ, Goforth L, Friderici K, Fisher R, Van Camp G, Berlin Cl, Oddoux C, Ostrer H, Keats B, Friedman TB (1998) Mutations in the connexin 26 gene (GJB2) among Ashkenazi Jews with nonsyndromic recessive deafness. The New England Journal of Medicine 339(21):1500-5.

https://doi.org/10.1056/NEJM199811193392103

Norouzi V, Azizi H, Fattahi Z, Esteghamat F, Bazazzadegan N, Nishimura C, Nikzat N, Jalalvand K, Kahrizi K, Smith RJH, Najmabadi H (2011) Did the GJB2 35delG mutation originate in Iran? American Journal of Medical Genetics Part A 155A(10):2453-8. https://doi.org/10.1002/ajmg.a.34225

Neocleous V, Costi C, Shammas C, Spanou E, Anastasiadou V, Tanteles GA, Phylactou LA (2014) Spectrum of GJB2 mutations in Cypriot nonsyndromic hearing loss subjects. Journal of Genetics 93(2):471-476. https://doi.org/10.1007/s12041-014-0365-0

Padma G, Ramchander PV, Nandur UV, Padma T (2009) GJB2 and GJB6 gene mutations found in Indian probands with congenital hearing impairment. Journal of Genetics 88(3):267-272.

https://doi.org/10.1007/s12041-009-0039-5

Patterson N, Price AL, Reich D (2006) Population structure and eigenanalysis. PLoS Genet 2(12):e190. https://doi.org/10.1371/journal.pgen.0020190 
Pollak A, Skórka A, Mueller-Malesińska M, Kostrzewa G, Kisiel B, Waligóra J, Krajewski P, Ołdak M, Korniszewski L, Skarżyński H, Ploski R (2007) M34T and V37I mutations in GJB2 associated hearing impairment: Evidence for pathogenicity and reduced penetrance. American Journal of Medical Genetics Part A 143A(21):2534-2543. https://doi.org/10.1002/ajmg.a.31982

Posukh OL, Zytsar MV, Bady-Khoo MS, Danilchenko VY, Maslova EA, Barashkov NA, Bondar AA, Morozov IV, Maximov VN, Voevoda MI (2019) Unique Mutational Spectrum of the GJB2 Gene and its Pathogenic Contribution to Deafness in Tuvinians (Southern Siberia, Russia): A High Prevalence of Rare Variant c.516G $>\mathrm{C}$ (p.Trp172Cys). Genes (Basel) 10(6):429. https://doi.org/10.3390/genes10060429

Rădulescu L, Mârţu C, Birkenhäger R, Cozma S, Ungureanu L, Laszig R (2012) Prevalence of mutations located at the dfnb1 locus in a population of cochlear implanted children in eastern Romania. International Journal of Pediatric Otorhinolaryngology 76(1):90-94. https://doi.org/10.1016/j.ijporl.2011.10.7

Raghavan M, Skoglund P, Graf K, Metspalu M, Albrechtsen A, Moltke I, Rasmussen S, Stafford Jr TW, Orlando L, Metspalu E, Karmin M, Tambets K, Rootsi S, Mägi R, Campos PF, Balanovska E, Balanovsky O,

Khusnutdinova E, Litvinov S, Osipova LP, Fedorova SA, Voevoda MI, DeGiorgio M, Sicheritz-Ponten T, Brunak S, Demeshchenko S, Kivisild T, Villems R, Nielsen R, Jakobsson M, Willerslev E (2013) No Evidence from GenomeWide Data of a Khazar Origin for the Ashkenazi Jews. Human Biology 85(6):859-900.

https://doi.org/10.3378/027.085.0604

RamShankar M, Girirajan S, Dagan O, Ravi Shankar HM, Jalvi R, Rangasayee R, Avraham KB, Anand A. (2003) Contribution of connexin26 (GJB2) mutations and founder effect to non-syndromic hearing loss in India. Journal of Medical Genetics 40(5):e68. https://doi.org/10.1136/jmg.40.5.e68

Rasmussen M, Li Y, Lindgreen S, Pedersen JS, Albrechtsen A, Moltke I, Metspalu M, Metspalu E, Kivisild T, Gupta R, Bertalan M, Nielsen K, Gilbert MTP, Wang Y, Raghavan M, Campos P.F, Kamp H.M, Wilson Andrew S, Gledhill Andrew R, Tridico S, Bunce M, Lorenzen E.D, Binladen J, Guo X, Zhao J, Zhang X, Zhang H, Li Z, Chen M, Orlando L, Kristiansen K, Bak M, Tommerup N, Bendixen C, Pierre TL, Gronnow B, Meldgaard M, Andreasen C, Fedorova SA, Osipova LP, Higham TFG, Ramsey CB, Hansen TvO, Nielsen FC, Crawford MH, Brunak S, Sicheritz-Ponten T, Villems R, Nielsen R, Krogh A, Wang J, Willerslev E (2010) Ancient human genome sequence of an extinct Palaeo-Eskimo. Nature 463(7282):757-62. https://doi.org/10.1038/nature08835

Rothrock CR, Murgia A, Sartorato EL, Leonardi E, Wei S, Lebeis SL, Yu LE, Elfenbein JL, Fisher RA, Friderici KH (2003) Connexin 26 35delG does not represent a mutational hotspot. Human Genetics 113(1):18-23. https://doi.org/10.1007/s00439-003-0944-2

Sansović I, Knežević J, Musani V, Seeman P, Barišić I, Pavelić J (2009) GJB2 Mutations in Patients with Nonsyndromic Hearing Loss from Croatia. Genetic Testing and Molecular Biomarkers 13(5):693-699. https://doi.org/10.1089/gtmb.2009.73

Santos RL, Aulchenko YS, Huygen PL, Van der Donk PL, de Wijs IJ, Kemperman MH, Admiraal RJ, Kremer H, Hoefsloot LH, Cremers CW (2005) Hearing impairment in Dutch patients with connexin 26 (GJB2) and connexin 30 (GJB6) mutations. International Journal of Pediatric Otorhinolaryngology 69(2):165-74. https://doi.org/10.1016/j.ijporl.2004.08.015 
Seeman P, Sakmaryová I (2006) High prevalence of the IVS1+1G to A/GJB2 mutation among Czech hearing impaired patients with monoallelic mutation in the coding region of GJB2. Clinical Genetics 69(5):410-413. https://doi.org/10.1111/j.1399-0004.2006.602.x

Shahin H, Walsh T, Sobe T, Lynch E, King MC, Avraham KB, Kanaan M (2002) Genetics of congenital deafness in the Palestinian population: multiple connexin 26 alleles with shared origins in the Middle East. Human Genetics 110(3):284-9. https://doi.org/10.1007/s00439-001-0674-2

Shinagawa J, Moteki H, Nishio SY, Noguchi Y, Usami SI (2020) Haplotype analysis of GJB2 mutations: Founder effect or mutational hot spot? Genes (Basel) 11(3):250. https://doi.org/10.3390/genes11030250

Shubina-Oleinik O, Siniauskaya M, Merkulava E, Levaya-Smaliak A, Davydenko O, Danilenko N (2014) When should one look for IVS1+1G>A splice mutation in patients with nonsyndromic sensorineural hearing loss? Journal of Hearing Science 4(2):24-29.

Solovyev AV, Barashkov NA, Bady-Khoo MS, Zytsar MV, Posukh OL, Romanov GP, Rafailov AM, Sazonov NN, Alexeev AN, Dzhemileva LU, Khusnutdinova EK, Fedorova SA (2017) Reconstruction of SNP haplotypes with mutation c.-23+1G>A in human gene GJB2 (Chromosome 13) in some populations of Eurasia. Russian Journal of Genetics 53:936. https://doi.org/10.1134/S1022795417080099

Stenson PD, Mort M, Ball EV, Shaw K, Phillips AD, Cooper DN (2014) The Human Gene Mutation Database: building a comprehensive mutation repository for clinical and molecular genetics, diagnostic testing and personalized genomic medicine. Human Genetics 133(1):1-9. https://doi.org/10.1007/s00439-013-1358-4

Tassi F, Vai S, Ghirotto S, Lari M, Modi A, Pilli E, Brunelli A, Susca RR, Budnik A, Labuda D, Alberti F, Lalueza-Fox C, Reich D, Caramelli D, Barbujani G (2017) Genome diversity in the Neolithic Globular Amphorae culture and the spread of Indo-European languages. Proceedings of the Royal Society 284(1867):20171540. https://doi.org/10.1098/rspb.2017.1540

Tataru P, Bataillon T, Hobolth A (2015) Inference Under a Wright-Fisher Model Using an Accurate Beta Approximation. Genetics 201(3):1133-41. https://doi.org/10.1534/genetics.115.179606

Tekin M, Arıcı ZS (2007) Genetic epidemiological studies of congenital/prelingual deafness in Turkey: Population structure and mating type are major determinants of mutation identification. American Journal of Medical Genetics Part A 143A(14):1583-1591. https://doi.org/10.1002/ajmg.a.31702

Tekin M, Xia XJ, Erdenetungalag R, Cengiz FB, White TW, Radnaabazar J, Dangaasuren B, Tastan H, Nance WE, Pandya A (2010) GJB2 Mutations in Mongolia: Complex Alleles, Low Frequency, and Reduced Fitness of the Deaf. Annals of Human Genetics 74(2):155-164. https://doi.org/10.1111/j.1469-1809.2010.564.x

The 1000 Genomes Project Consortium (2015) A global reference for human genetic variation. Nature 526(7571):68-74. https://doi.org/10.1038/nature15393

Tóth T, Kupka S, Haack B, Fazakas F, Muszbek L, Blin N, Pfister M, Sziklai I (2007) Coincidence of mutations in different connexin genes in Hungarian patients. International Journal of Molecular Medicine 20(3):315-21. https://doi.org/10.3892/ijmm.20.3.315 
Tsukada K, Nishio S, Hattori M, Usami S. Ethnic-Specific Spectrum of GJB2 and SLC26A4 Mutations (2015):

Their Origin and a Literature Review. Annals of Otology, Rhinology \& Laryngology. 124(1_suppl):61S-76S. doi:10.1177/0003489415575060

Utrera R, Ridaura V, Rodríguez Y, Rojas MJ, Mago L, Angeli S, Henríquez O (2007) Detection of the 35delG/GJB2 and del(GJB6-D13S1830) Mutations in Venezuelan Patients with Autosomal Recessive Nonsyndromic Hearing Loss. Genetic Testing 11(4):347-352. https://doi.org/10.1089/gte.2006.526

Van Laer L, Coucke P, Mueller RF, Caethoven G, Flothmann K, Prasad SD, Chamberlin GP, Houseman M, Taylor GR, Van de Heyning CM, Fransen E, Rowland J, Cucci RA, Smith RJ, Van Camp G (2001) A common founder for the 35delG GJB2 gene mutation in connexin 26 hearing impairment. Journal of Medical Genetics 38(8):515-8. https://doi.org/10.1136/jmg.38.8.515

Yan D, Park HJ, Ouyang XM, Pandya A, Doi K, Erdenetungalag R, Du LL, Matsushiro N, Nance WE, Griffith AJ, Liu XZ (2003) Evidence of a founder effect for the 235delC mutation of GJB2 (connexin 26) in East Asians. Human Genetics 114(1):44-50. https://doi.org/10.1007/s00439-003-1018-1

Yuan Y, Yu F, Wang G, Huang S, Yu R, Zhang X, Huang D, Han D, Dai P (2010) Prevalence of the GJB2 IVS1+1G $>A$ mutation in Chinese hearing loss patients with monoallelic pathogenic mutation in the coding region of GJB2. Journal of Translational Medicine 8(1):127. https://doi.org/10.1186/1479-5876-8-127

Yunusbayev B, Metspalu M, Järve M, Kutuev I, Rootsi S, Metspalu E, Behar DM, Varendi K, Sahakyan H, Khusainova R, Yepiskoposyan L, Khusnutdinova EK, Underhill PA, Kivisild T, Villems R (2012) The Caucasus as an Asymmetric Semipermeable Barrier to Ancient Human Migrations. Molecular Biology and Evolution 29(1):359-65. https://doi.org/10.1093/molbev/msr221

Zytsar MV, Barashkov NA, Bady-Khoo MS, Shubina-Olejnik OA, Danilenko NG, Bondar AA, Morozov IV, Solovyev AV, Danilchenko VYu, Maximov VN, Posukh OL (2018) Updated carrier rates for c.35delG (GJB2) associated with hearing loss in Russia and common c.35delG haplotypes in Siberia. BMC Medical Genetics 19(1):138. https://doi.org/10.1186/s12881-018-0650-5

Zytsar MV, Bady-Khoo MS, Danilchenko VY, Maslova EA, Barashkov NA, Morozov IV, Bondar AA, Posukh OL (2020) High Rates of Three Common GJB2 Mutations c.516G>C, c.-23+1G>A, c.235delC in Deaf Patients from Southern Siberia Are Due to the Founder Effect. Genes (Basel) 11(7):833.

https://doi.org/10.3390/genes11070833

\section{Figures}


A

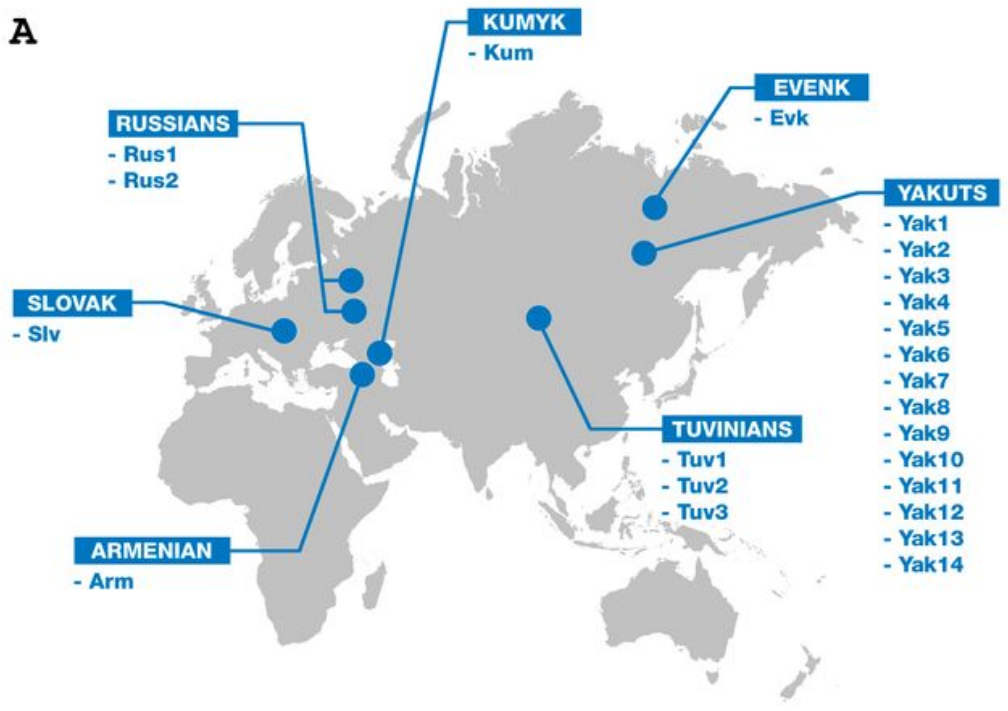

B

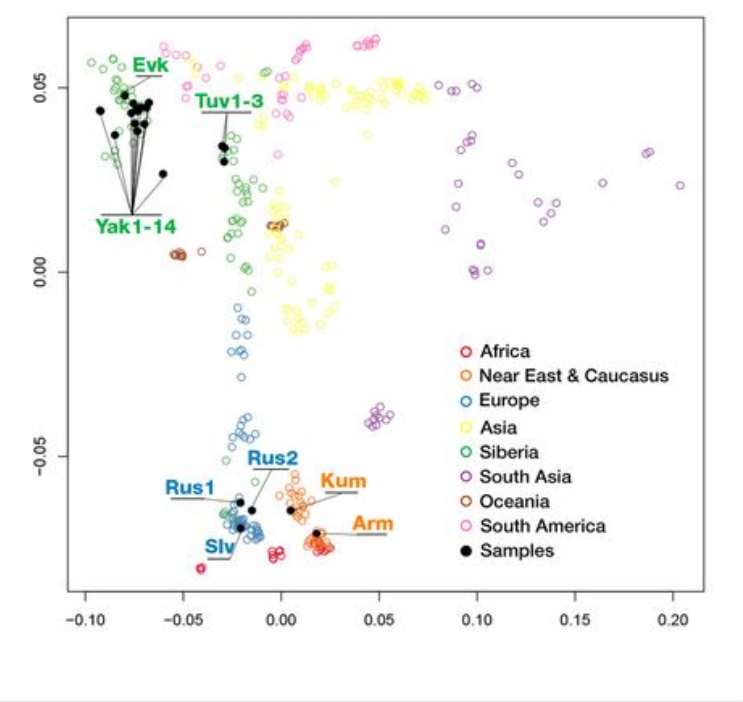

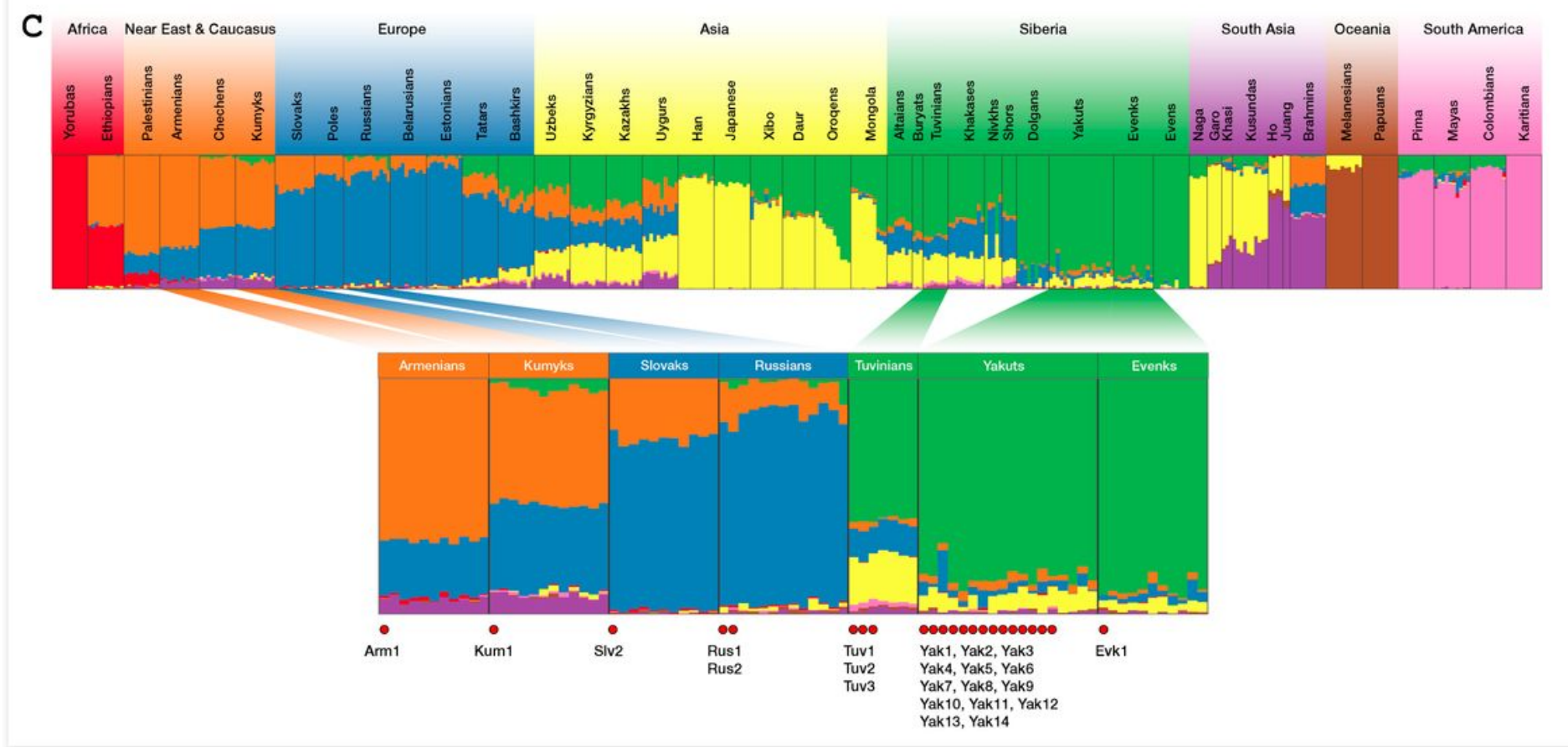

Figure 1

Geographical and genetic characteristics of individuals homozygous for $\mathrm{c} .-23+1 \mathrm{G}>\mathrm{A}$. For better perception of the ADMIXTURE analysis, we selected ten individuals from every population. A - Place of birth of investigated deaf individuals; B - PC plot of studied samples and 391 individuals from 24 different worldwide populations; C - Analysis of genetic lineages of studied samples compared to 391 individuals from 24 populations of the world (ADMIXTURE $K=8)$. Each individual is represented by a $(100 \%)$ stacked column indicating the proportions of the pedigree in $\mathrm{K}$, constructed by the ancestral populations. The lower panel of the figure represents deaf individuals homozygous for the $\mathrm{c} .-23+1 \mathrm{G}>\mathrm{A}$ marked by red dots. 


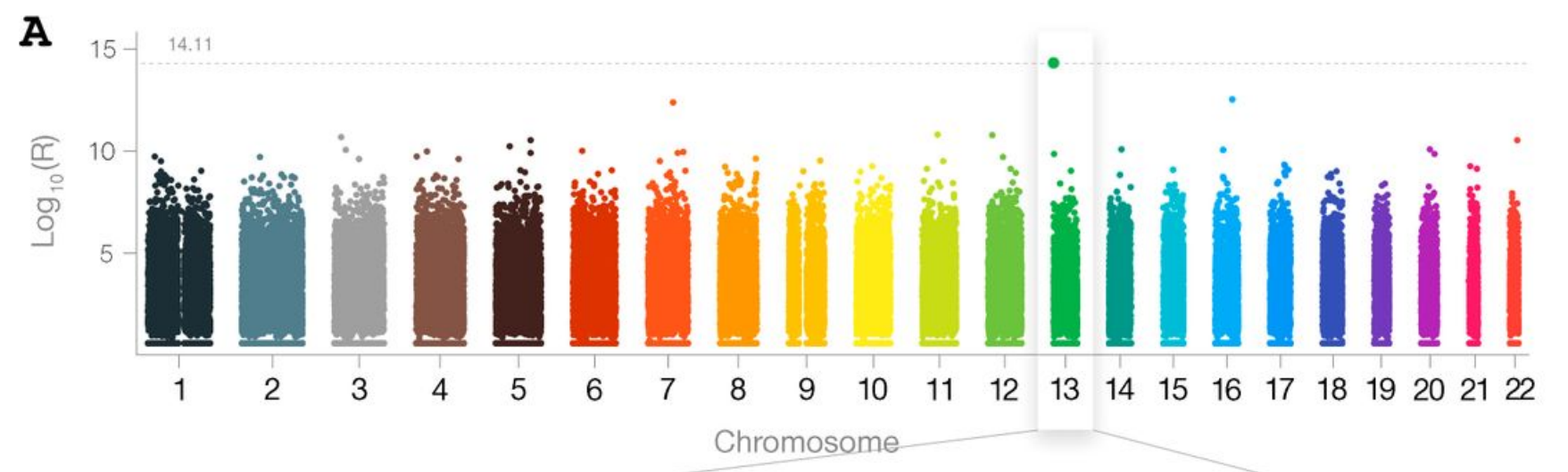

B

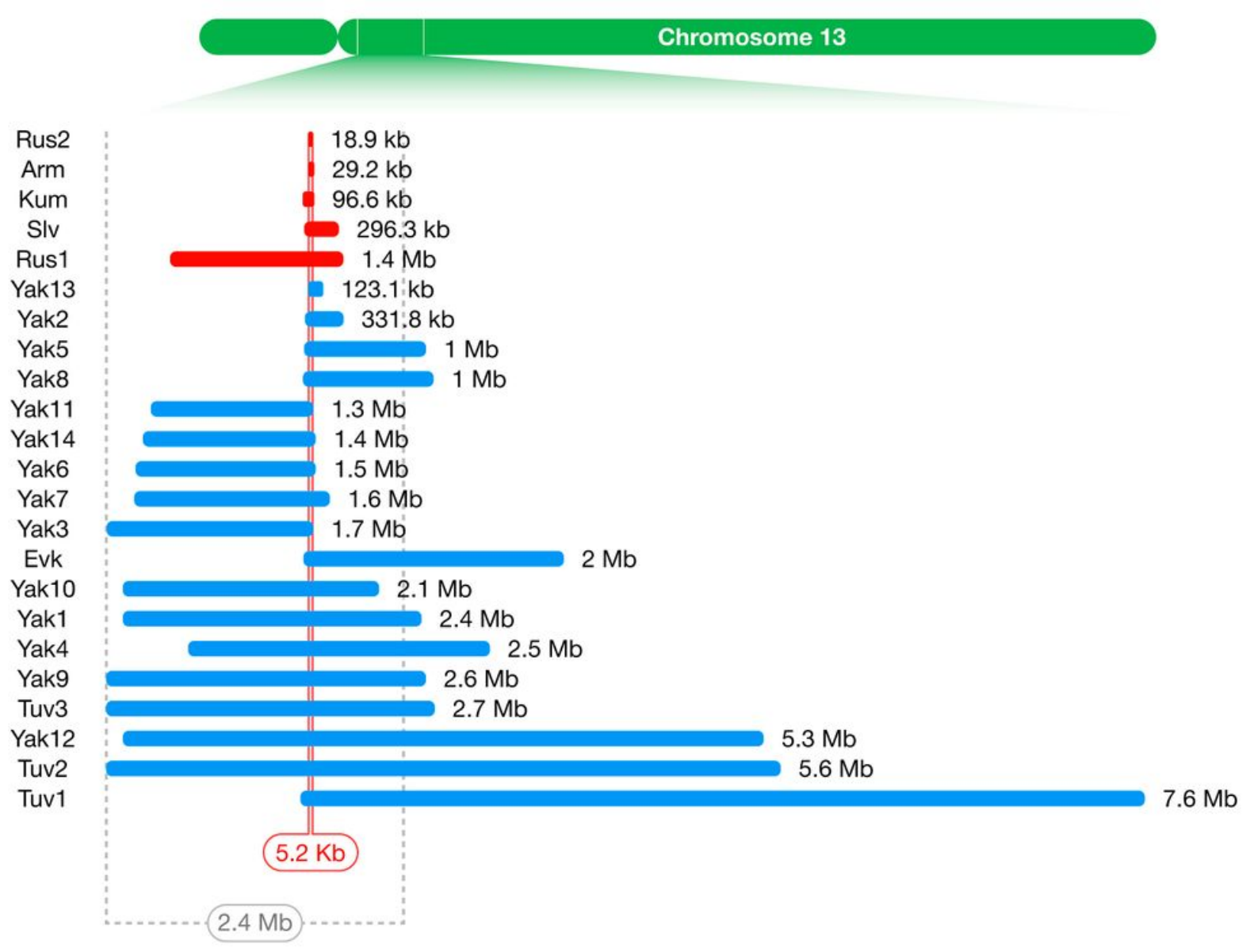

\section{Figure 2}

Common chromosomal region for the c.-23+1G>A mutation in the GJB2 gene in all studied individuals. A Common chromosomal region in the total sample of 23 homozygotes for the c.-23+1G>A; B - Detailed analysis of homozygosity region in studied deaf individuals. Individuals of European descent are shown in red color; individuals of Siberian descent are shown in blue color. 

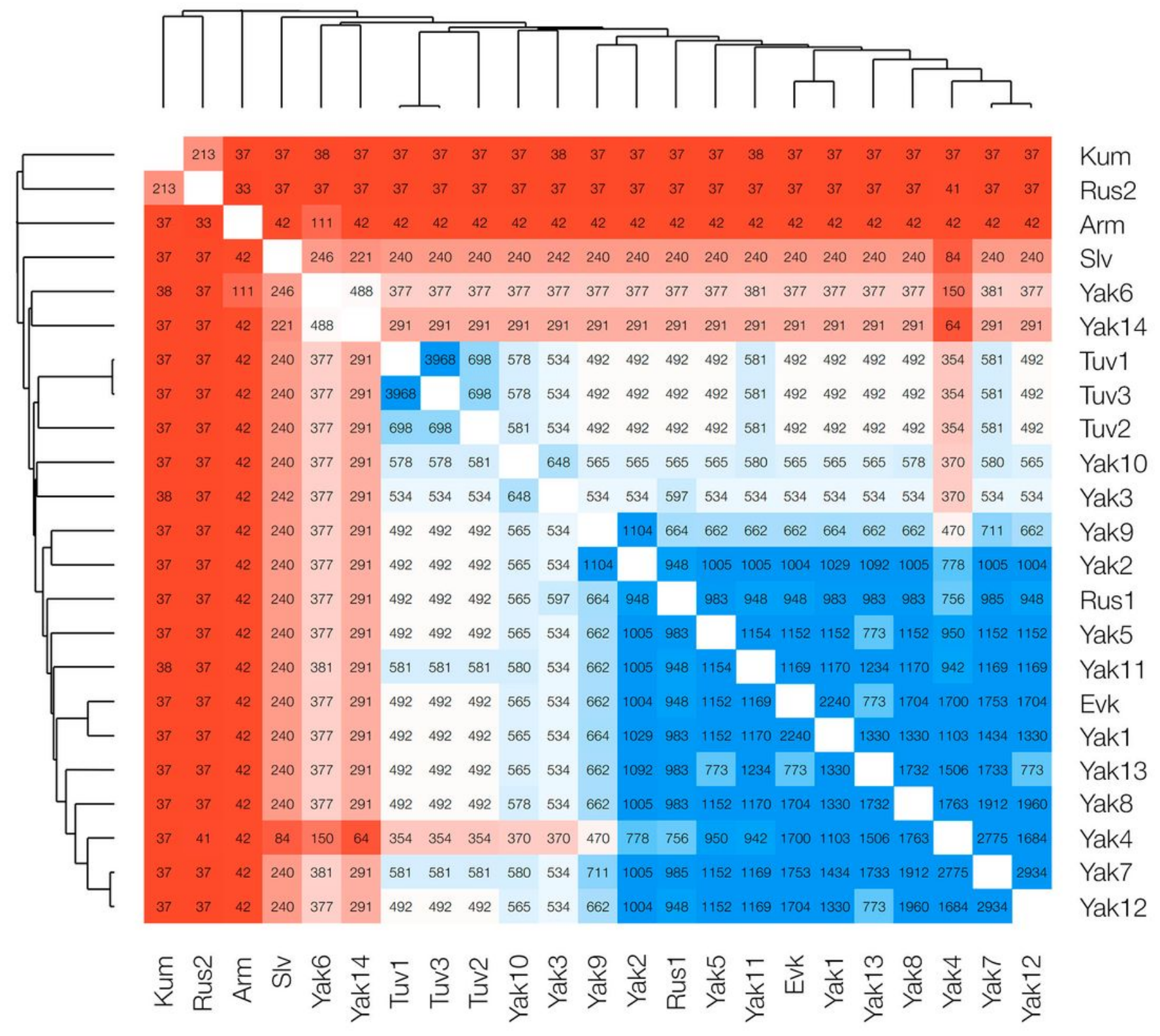

\section{Figure 3}

The length of the $f 2$-haplotypes. Note: The dendrogram was constructed using the UPGMA method based on the length of the $f 2$-haplotypes, not given the number of heterozygous alleles; short $f$ 2-haplotypes (mostly individuals of European descent) are shown in red color; long $f$ 2-haplotypes (mostly individuals of Siberian descent) are shown in blue color. 


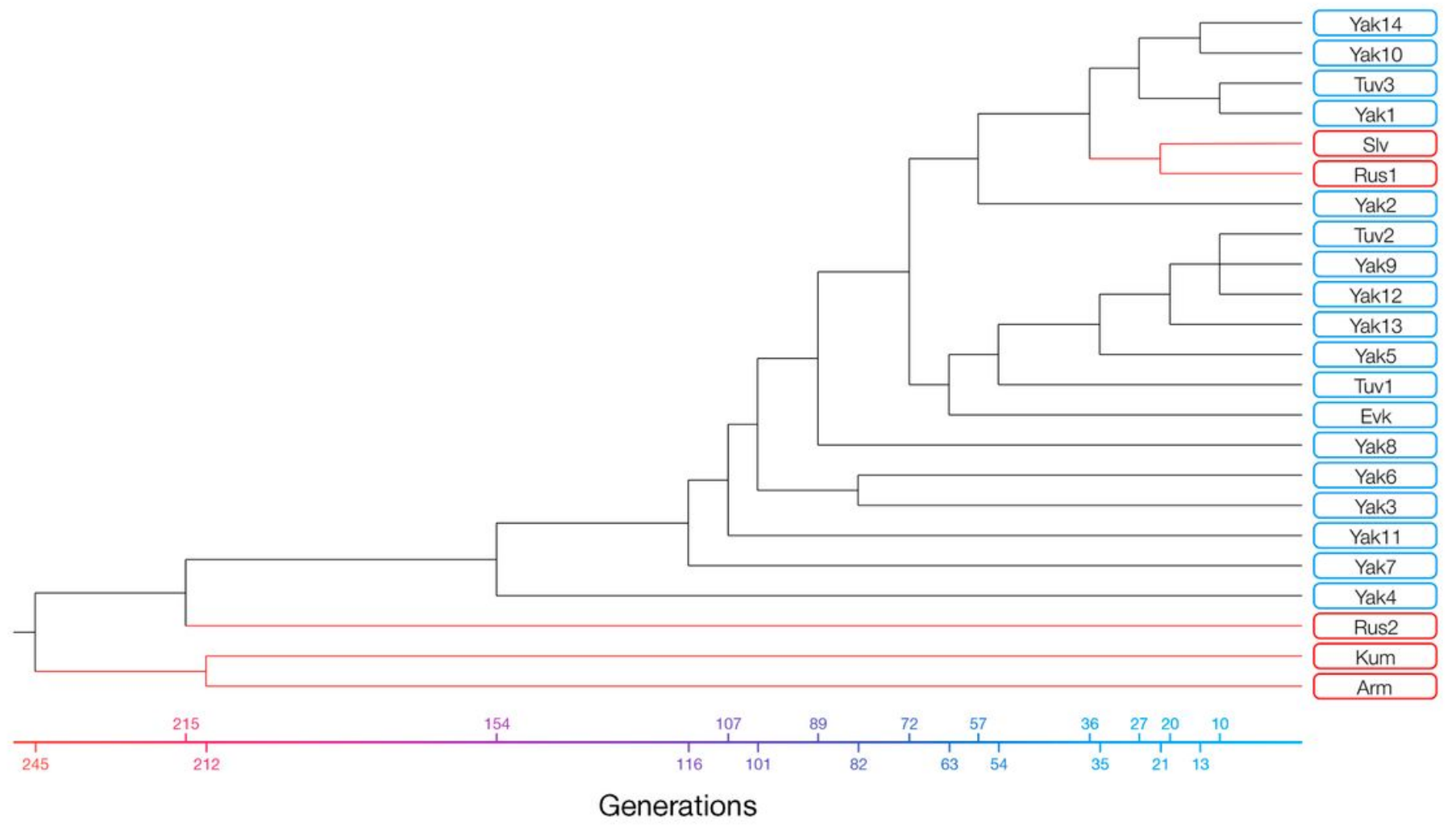

Figure 4

UPGMA dendrogram showing the Time to Most Recent Common Ancestor (TMRCA) between each of the $f 2$ haplotypes.

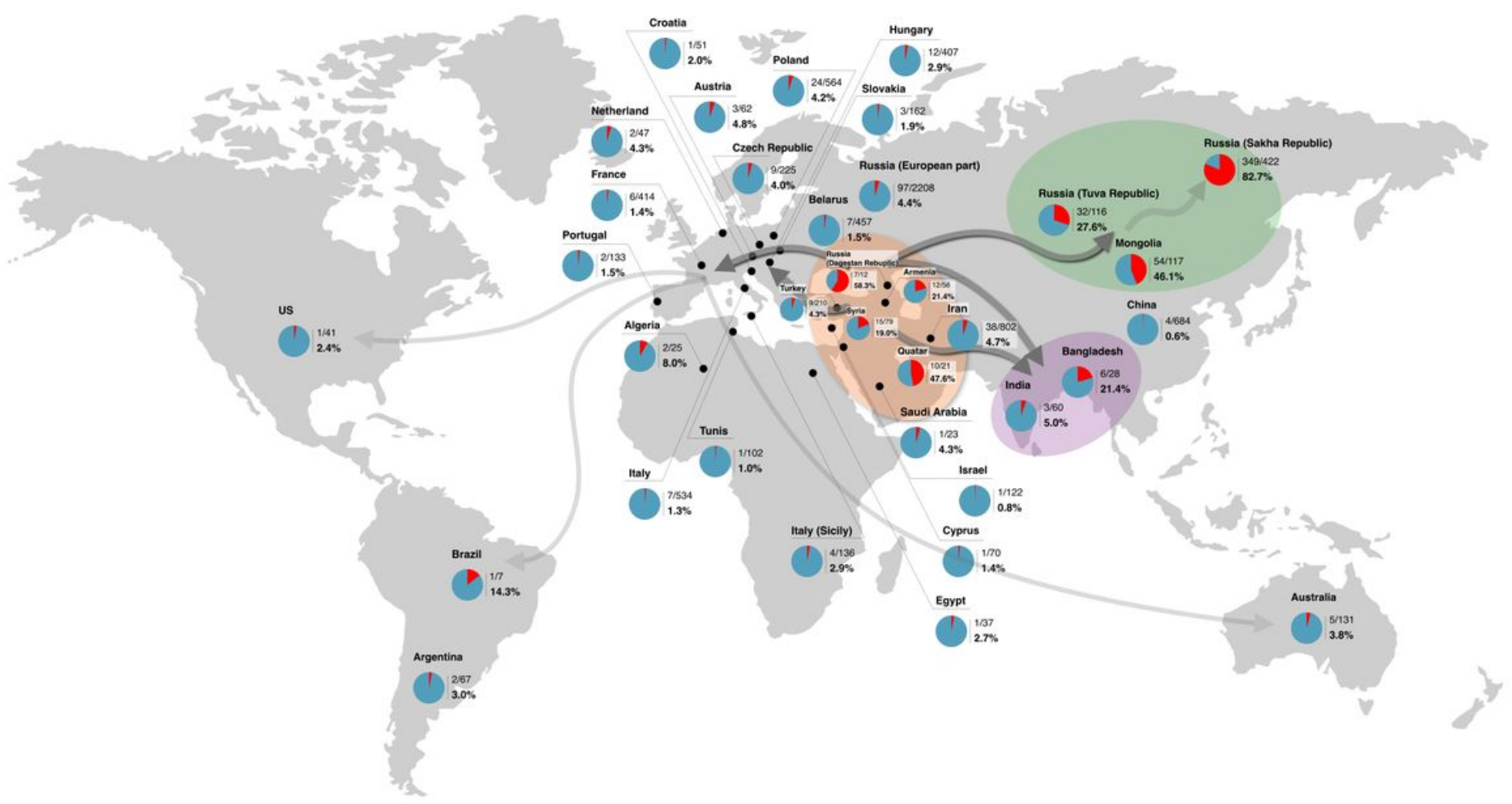


Figure 5

Supposed geographical center of the $c .-23+1 \mathrm{G}>A$ mutation origin and the proportions of the $c .-23+1 \mathrm{G}>\mathrm{A}$ among mutant GJB2 chromosomes in different world populations. Note: The orange area is a possible place of origin of the $c .23+1 \mathrm{G}>\mathrm{A}$ mutation. Purple area is the $\mathrm{c} .23+1 \mathrm{G}>\mathrm{A}$ mutation accumulation center in South Asia. Green area is the mutation accumulation in Central Asia and Siberia. Gray arrows demonstrate possible migration routes of the carriers of $c .23+1 \mathrm{G}>A$ mutation across the world. In pie charts: a proportion of the c. $-23+1 \mathrm{G}>\mathrm{A}$ mutation is shown by red color; other mutations in the GJB2 gene are shown by blue color.

\section{Supplementary Files}

This is a list of supplementary files associated with this preprint. Click to download.

- SupplementaryTable.docx 